Original Research Paper

\title{
Impact Assessment of Soil Contamination with Antibiotics (for Example, an Ordinary Chernozem)
}

\author{
Yuliya Viktorovna Akimenko, Kamil Shagidullovich Kazeev and Sergey Ilyich Kolesnikov \\ Academy of Biology and Biotechnology, Southern Federal University, \\ 344006, Russia, Rostov-on-Don, Bolshaya Sadovaya Str., 105/42, Russia
}

\author{
Article history \\ Received: 04-12-2014 \\ Revised: 26-02-2015 \\ Accepted: 28-02-2015 \\ Corresponding Author: \\ Yuliya Viktorovna Akimenko \\ Academy of Biology and \\ Biotechnology, Southern \\ Federal University, 344006, \\ Russia, Rostov-on-Don, \\ Bolshaya Sadovaya Str., \\ 105/42, Russia \\ Email: akimenkojuliya@mail.ru
}

\begin{abstract}
The environmental behavior of antibiotics is not well known and the precise environmental risk assessment is not practical. We studied the impact antibiotics (benzylpenicillin, pharmasin and nystatin) at different concentrations (100 and $600 \mathrm{mg} \mathrm{kg}^{-1}$ ) on population densities of microorganisms and enzymatic activity of ordinary chernozems in model experiments. The applied doses of antibiotics had definite suppressing effects on population densities of microorganisms (up to $30-70 \%$ of the control) and on the soil enzymatic activity (20-70\% of the control). The correlation analysis of the obtained data revealed positive correlation of enzymes of two studied classes (dehydrogenase, invertase) with a number of micromycetes $(r=0.63, r=0.65$, respectively), catalases with ammonifying bacteria $(\mathrm{r}=0.73)$ and the return correlation of phosphatase with amylolytic bacteria $(r=-0.80)$. The effect of antibiotics on the biological properties of the chernozem lasted for a long time. The studied parameters were not completely recovered in 120 days.
\end{abstract}

Keywords: Benzylpenicillin, Pharmasin, Nystatin, Ordinary Chernozem, Microorganisms, Biological Properties

\section{Introduction}

Tons of pharmacologically active substances are used annually in human and animal medicines for treatment and prevention of illness (Diraz-Cruz et al., 2003; Sarmah et al., 2006). Antibiotics get into ecosystems in the initial form or in the form of some metabolites that mainly remain biologically active (Sarmah et al., 2006). In contrast to pesticides, antibiotics did not attract interest as potential contaminants until recently (Thiele-Bruhn, 2003). Antibiotics enter the soil mostly with manure (Kemper, 2008; Zhao et al., 2010) and sewage water (Golet et al., 2003) applied as fertilizers. Various antibiotics are found in ground and waste water and in soil (Ramaswamy et al., 2010; Pereira et al., 2012; Sirés and Brillas, 2012; Zhou et al., 2013). Once in the environment, like any other organic chemicals, their efficacy depends on their physio-chemical properties, prevailing climatic conditions, soil types and variety of other environmental factors.

Residues of pharmaceutical antibiotics have already been discovered in soils in concentrations of up to 300 $\mathrm{ng} \mathrm{g}^{-1}$ for tetracyclines and $11 \mathrm{ng} \mathrm{g}^{-1}$ for sulfonamides (Hamscher et al., 2005; Höper et al., 2002). High concentrations of tetracyclines have been detected in
Turkey and Spain soils, up to 0.5 and $0.2 \mathrm{mg} \mathrm{kg}^{-1}$, respectively (Andreu et al., 2009; Karci and Balcioglu, 2009). Concentrations of $20 \mathrm{mg} \mathrm{L}^{-1}$ of tetracycline and 1 $\mathrm{mg} \mathrm{L}^{-1}$ of chlortetracycline have been detected in liquid manure or in swine lagoon (Campagnolo et al., 2002). Additionally, various antibiotics are naturally formed in soils, though the concentrations and types of antibiotics getting into soils and water from external sources differ from those of the natural background (Zhang et al., 2009). Antibiotics can also be introduced to agricultural land through irrigation with reclaimed wastewater, since they have been frequently detected in the raw and treated sewage wastewaters (Renew and Huang, 2004; Yang et al., 2005; Gulkowska et al., 2008). Microorganisms become resistant to the antibiotics that are widespread in the environment. Bacterial resistance has been a big issue in terms of human and animal health (Nakatani et al., 2012). While it is possible that antibiotics can find their way into the environment from a variety of sources, whether or not there are adverse effects to human, terrestrial and aquatic ecosystems is not well understood.

The goal of this study was to investigate the effect of various pharmaceutical antibiotics on the abundance of microorganisms and enzymes activity in ordinary chernozem. 
This study is a part of a series of scientific studies on the effect of biologically active substances on the biological indicators of soil in southern Russia.

\section{Materials and Methods}

\section{Antibiotics}

We took widely used in medicine and animal husbandry bactericidal (benzylpenicillin), bacteriostatic (pharmasin/tylosin) and fungicidal (nystatin) antibiotics to study their impacts on the soil microbiota and enzymatic activity. Benzylpenicillin is an antibiotic of the biosynthetic penicillin group. It produces bacteriocidal effects by the inhibition of bacterial cell wall synthesis. Benzylpenicillin is active against gram-positive and gramnegative bacteria, anaerobic spore-forming rods. Pharmasin is a drug widely used in veterinary medicine; it contains tylosin as the active compound. Tylosin is an antibiotic of macrolide group; it is active against most gram-positive and some gram-negative bacteria. Nystatin is polyene antifungal antibiotic. It affects pathogenic fungi and yeast-like fungi of genus Candida, as well as Aspergillus and is inactive against bacteria.

\section{Soil}

Deep heavy loamy calcareous low-humus ordinary chernozem developed from yellow-brown loess like loams in the Botanical Garden of the Southern Federal University (Rostov-on-Don) was studied. Such soils are typical of the south of European Russia and have special significance in ensuring food security of the country (Val'kov et al., 2008). Soil samples for model experiments were taken from the plow horizon $(0-25$ $\mathrm{cm})$. The width of chernozem humus horizon is about 80 $\mathrm{cm}$, the soil texture is hard-loamy soil, the medium reaction is 7.7 , humus content is $4.1 \%$, total nitrogen (by Kjeldahl)- $0.25 \%$; mobile phosphorus (by Machigin)28.8; total potassium (by Berzelius)-2.06\%

\section{Experimental Test Procedure}

Air-dried soil samples were treated with solutions of benzylpenicillin and pharmasin and with their complexes with nystatin in concentrations of 100 and $600 \mathrm{mg} \mathrm{kg}^{-1}$ soil. These concentrations were taken on the basis of literature data on residual quantities of antibiotics in the environment (Chander et al., 2005; Hu et al., 2010) and according to the results of preliminary studies. Within the dose range of $10-600 \mathrm{mg} \mathrm{kg}^{-1}$, the minimum effect was observed at concentrations of $100 \mathrm{mg} \mathrm{kg}^{-1}$ and the maximum effect took place at concentrations of $600 \mathrm{mg}$ $\mathrm{kg}^{-1}$ (Akimenko et al., 2013a; 2014a; 2014b). All the samples were incubated at $20-25^{\circ} \mathrm{C}$ in dark place in order to avoid quick destruction of antibiotics at the optimum moisture content $(60 \%$ of the field water capacity). Soil not subjected to treatment with antibiotics was used as the control. The changes in population density of microorganisms and enzymatic activity were studied after 10, 60 and 120 days of incubation. Analytical determinations of the biological properties were performed in four replicates.

Statistics were calculated using Statistica 6.0. Significant differences were accepted at $\mathrm{p}<0.05, \mathrm{p}<0.01$ and $\mathrm{p}<0.001$. Spearman's rank correlation coefficient was calculated.

\section{Microbial Activity Tests}

Multiple studies of the microbial cenosis in the ordinary chernozem included the determination of population density of microorganisms by the method of deep inoculation from corresponding dilutions onto solid nutrient media: Ammonifying bacteria on Meat Infusion Agar (MIA), amylolytic bacteria on Starch and Ammonia Agar (SAA), micromycetes on acidified Czapek's medium, nitrogen-fixing bacteria (genus Azotobacter) on an Ashbymedium (soil plaque method) (Zvyagintsev, 1991).

\section{Enzymes Activity Tests}

The catalase activity was measured by the Galstyan method; the dehydrogenase activity, by the Galstyan method modified by Khaziev; the phosphatase activity, by the modified method of Galstyan and Arutyunyan; and the invertase activity, by the modified colorimetric method of Khaziev (Kazeev and Kolesnikov, 2012).

\section{Results}

Antibiotics may change the bacterial diversity and resistance of soil communities by increasing selection pressure in favour of resistant phenotypes (Čermák et al., 2008). The results obtained in this study demonstrate (Fig. 1 and 2) that all the studied concentrations of antibiotics have a suppressing effect on population densities of soil microorganisms; the same result was obtained in (Colinas et al., 1994). At the same time, there are data attesting to astimulating effect of antibiotics in low concentrations (0.1-0.5 $\mathrm{mg} \mathrm{kg}^{-1}$ ) on microorganisms (Schmitt et al., 2004). Close correlation was found between concentrations of antibiotics and the change in population densities of the studied groups of soil microorganisms $(r=-0.68-0.86)$. Other studies demonstrated the dependence of the effects of antibiotics on soil microbiota on their concentrations (Herron et al., 1998). Thus, it was found that soil contamination with sulfachloropyridazine inhibited the soil microbiota, though further rise in the concentration of this antibiotic caused the development of resistance in microorganisms (Schmitt et al., 2004). The changes in the population density of ammonifying bacteria in the ordinary chernozem under the impact of antibiotics are shown in Fig. 1A. 


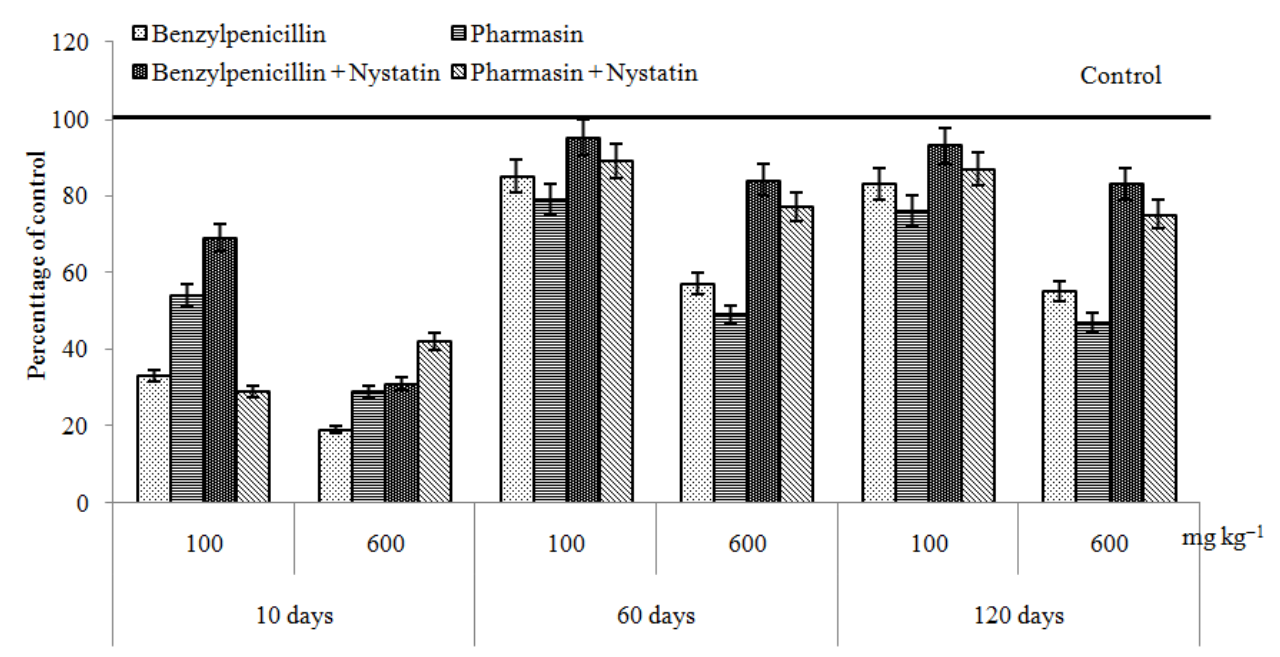

(A)

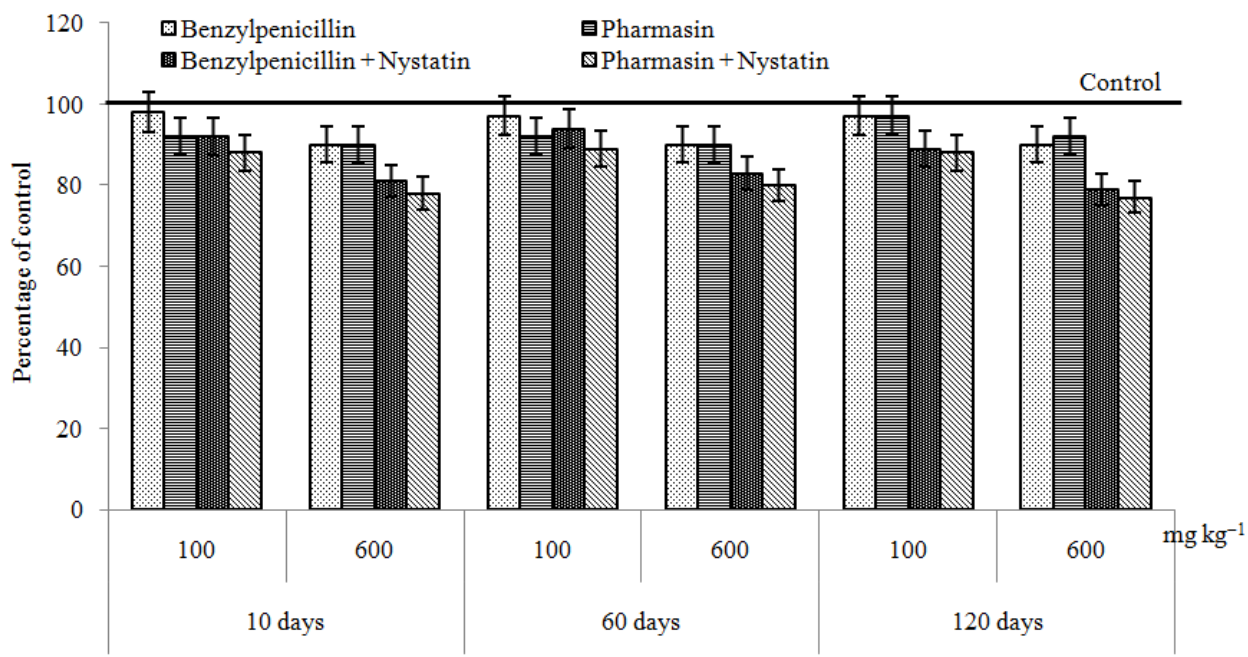

(B)

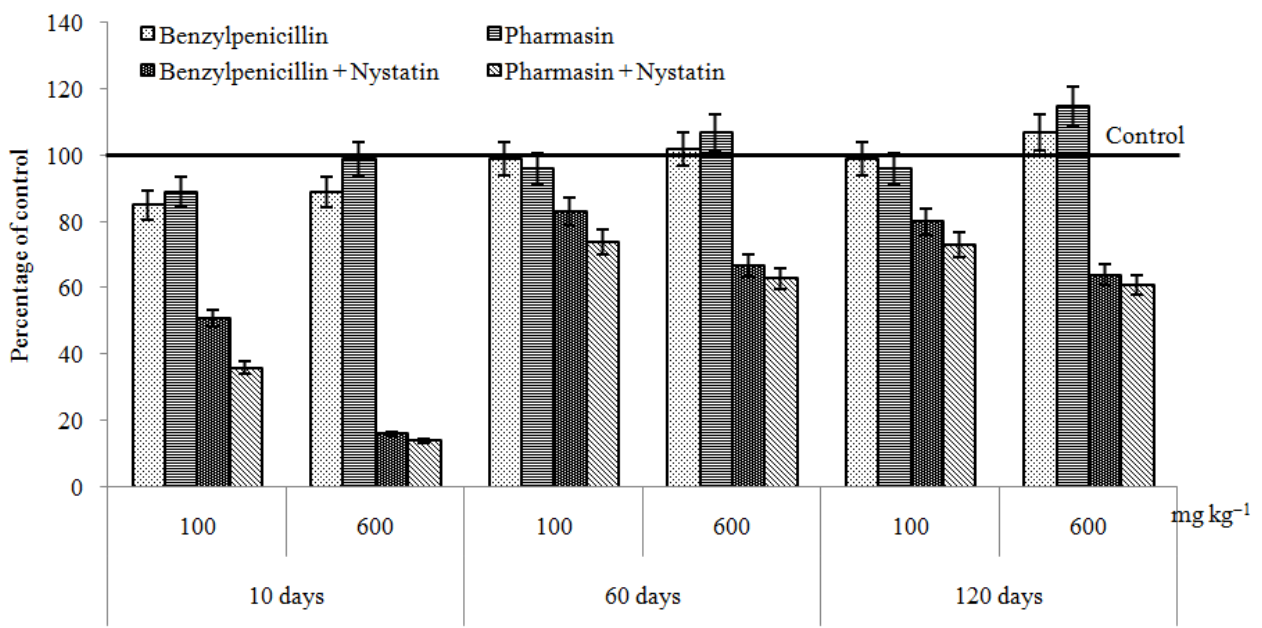

(C)

Fig. 1. Effect of antibiotics on the abundance of soil microorganism A (ammonifiers) B (amylolytic bacteria) C (micromycetes) 
The complex of pharmasin and nystatin had the maximum inhibiting effect on ammonifiers in concentration of $100 \mathrm{mg} \mathrm{kg}$; the complex of benzylpenicillin and nystatin in the same concentration had the minimum effect. Other researchers noted a decrease in the inhibiting effect onammonifiers in the presence of fungicidal preparations and a synergetic effect of the mixtures of antibiotics with similar action (Barlow et al., 2008; Brown and Balkwill, 2009). The reasons for such effects remain unknown. On the contrary, upon higher concentrations $\left(600 \mathrm{mg} \mathrm{kg}^{-1}\right)$, the decrease in population density of ammonifying bacteria under the impact of antibacterial antibiotics was more pronounced than that under the impact of their complexes with fungicidal preparation. The restoration of population density of bacteria was observed after 60 and 120 days of the experiment. It was virtually complete upon application of antibiotics in minimum concentration, $75-85 \%$ of the control in the case of maximum concentrations of antibiotic complexes $(p<0.05)$ and 45$58 \%(p<0.001)$ for antibacterial antibiotics. Similar data on the dynamics of the number of ammonifying bacteria were obtained in model experiments with different types of radiation (Denisova et al., 2005; 2011; Denisova and Kazeev, 2008). When contaminating with relatively small doses (up to 1 Maximum Permissible Concentration (MPC) of heavy metals (Kolesnikov et al., 2011; 2013) and oil and petroleum products (Kolesnikov et al., 2006; 2010a), the population density of microorganisms in increased in the first days from the moment of contamination (up to 1 month), then decreased and did not restore completely even after 360 days. However, the effects of antibiotics on soil microorganisms had a more prolonged character in comparison with the effects of high temperature sterilization (Akimenko et al., 2013b) and pesticides (Kazeev et al., 2010). In researches with pesticide atrazine (Moreno et al., 2007) it is shown that in general, an increase in the measured microbiological and biochemical parameters with atrazine concentration in soil was observed. The increase in microbial activity with atrazine pollution was noticeable after lengthy incubation. Thus, upon the soil sterilization with high temperature, the number of microorganisms was restored to the control values already on the 60th day.

The studied antibiotics in concentration of $100 \mathrm{mg}$ $\mathrm{kg}^{-1}$ did not exert significant inhibiting effect on the number of amylolytic bacteria (Fig. 1B). Population densities of amylolytic bacteria remained practically the same on the 10th and 120th days of the experiment. Significant inhibiting effects on amylolytic bacteria were observed under concentrations of antibiotics of $600 \mathrm{mg}$ $\mathrm{kg}^{-1}$ and complexes of antibiotics were most efficient. It was shown in other studies that antibiotics such as sulfonamide (Thiele-Bruhn, 2003), tetracycline and trimethoprim (Pallecchi et al., 2008) in concentrations $300-500 \mathrm{mg} \mathrm{kg}^{-1}$ had an inhibiting effect on amylolytic bacteria. Unlikeammonifying bacteria, the population density of amylolytic bacteria practically did not restore by the 120th day of experiment. At the same time, amylolyticbacteria appeared to be more resistant to the impact of studied antibiotics. As anticipated, antibacterial antibiotics (benzylpenicillin and pharmasin) at all the studied concentrations did not cause significant changes in population density of micromycetes in contrast to their complexes with nystatin. As shown earlier (Malygina and Kazeev, 2011), fungicidal antibiotic nystatin had no effects on soil bacteria, but decreased the number of soil micromycetes in concentrations of $100-600 \mathrm{mg} \mathrm{kg}^{-1}$. The suppressing effect of nystatin on the soil fungi was higher in the variants with high nystatin concentrations. The population density of micromycetes under the influence of the complex of antibiotics decreased by $45-55 \%(p<0.001)$ on the 10th day of the experiment and the population recovery up to $70-80 \%$ of the control was observed on the 120th day. However, no complete recovery took place $\mathrm{r}$. Complexes of antibiotics in concentration $600 \mathrm{mg} \mathrm{kg}^{-1}$ had significant inhibiting effect on the population density of micromycetes. Inhibiting effects of the complexes of nystatin with benzylpenicillin and pharmasin were practically similar. A tendency for the recovery of micromycetes (up to $60-65 \%$ of the control was observed $(p<0.001)$. A gradual increase in population density of micromycetes in comparison with the control was observed in variants with antibacterial antibiotics in concentration $600 \mathrm{mg} \mathrm{kg}^{-1}$; in this case, the population density of micromycetes exceeded the control by $10-18 \%(\mathrm{p}<0.05)$ on the 120th day of the experiment. This can be attributed to elimination of competition from bacteria and active colonization of their ecological niches bymicromycetes, or to their strong adaptation, or both (Fig. 1C).

The effect of pharmaceutical antibiotics on bacteria of genus Azotobacter was also investigated. Many studies demonstrated that genus Azotobacter is highly sensitive to pollution and it was suggested as a test object for the assessment of soil properties at different pollution (Kolesnikov et al., 2010b; Denisova et al., 2005). However, for all investigated antibiotics at concentration of $100 \mathrm{mg} \mathrm{kg}^{-1}$, statistically significant changes were not detected and the abundance of bacteria decreased by $20 \%$ $(p<0.05)$ in comparison with the control only with concentrations of complexes of antibiotics of $600 \mathrm{mg} \mathrm{kg}^{-1}$.

Long-term studies have shown the efficiency of the diagnostics and monitoring of soils with biochemical methods, particularly with the help of the indices of soil enzymatic activity. The use of enzymatic activity as a diagnostic parameter is favored by the low error of experiments, simplicity of determination and high sensitivity to external impacts (Galstyan, 1978; 1982; Dadenko et al., 2009). 


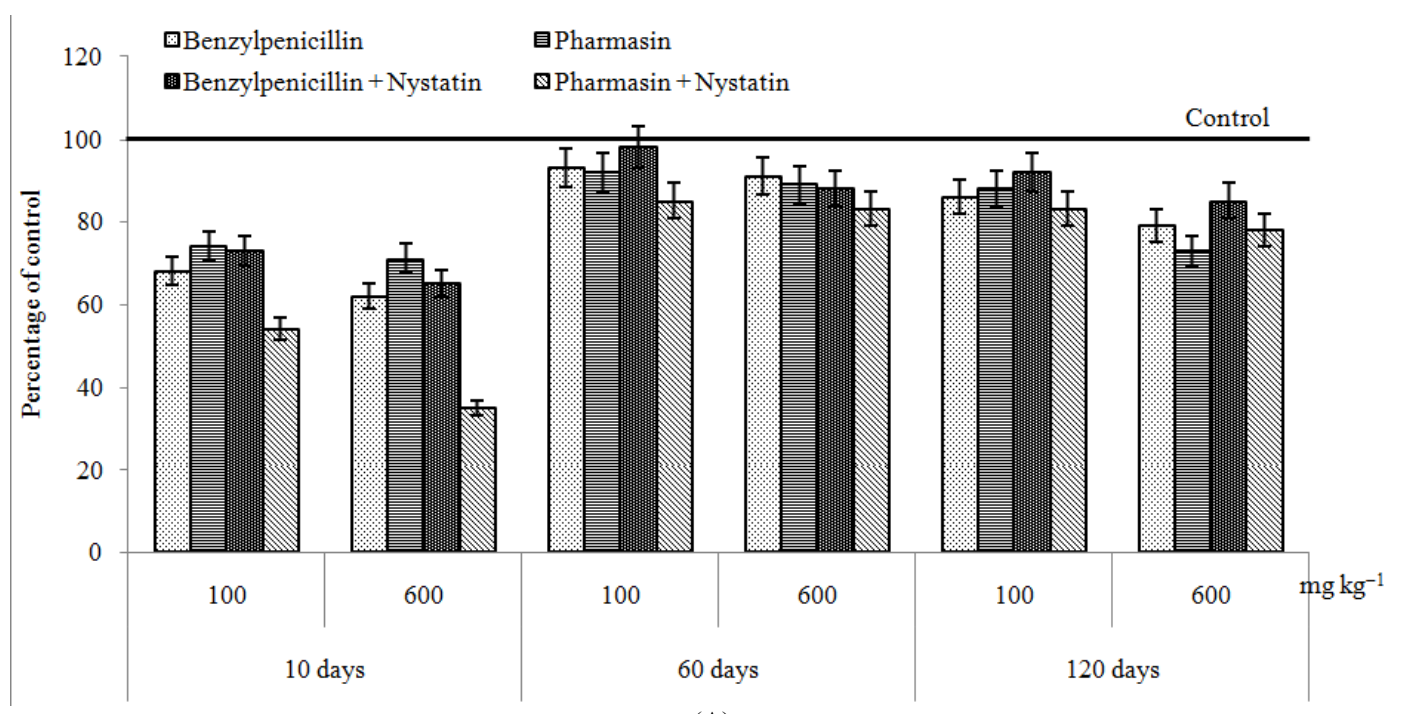

(A)

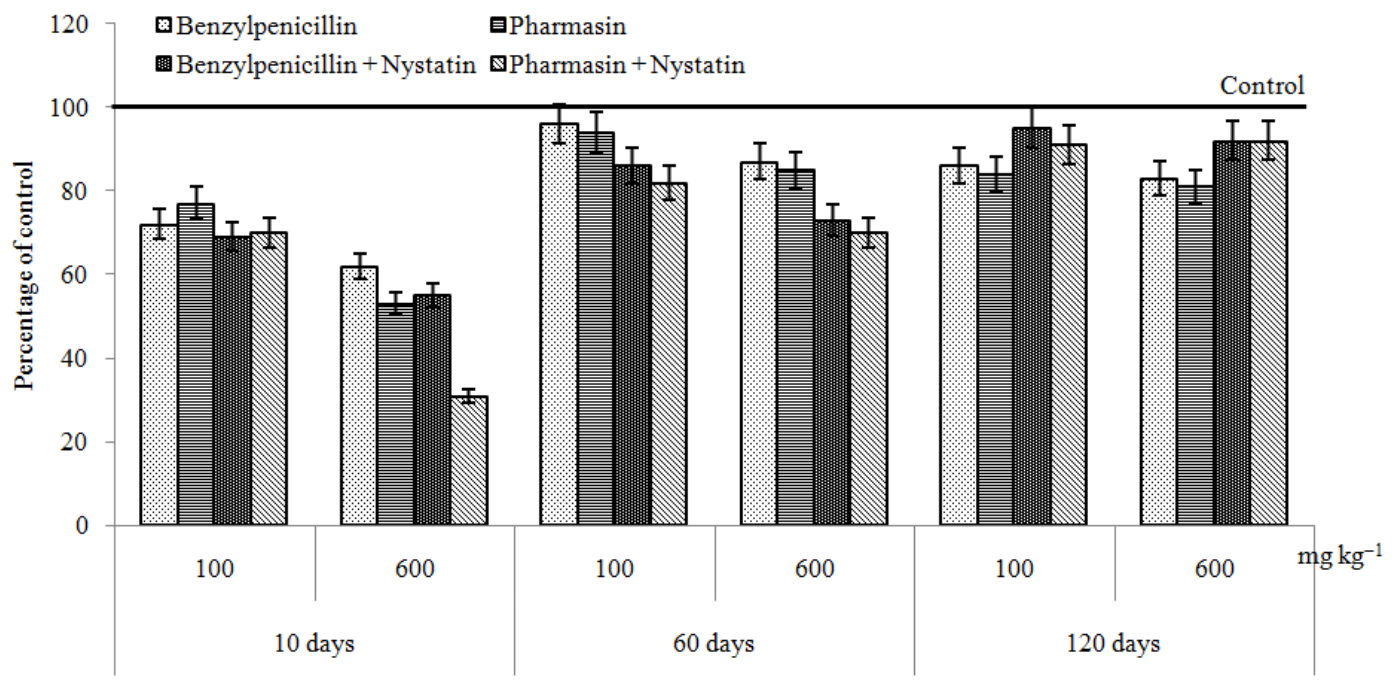

(B)

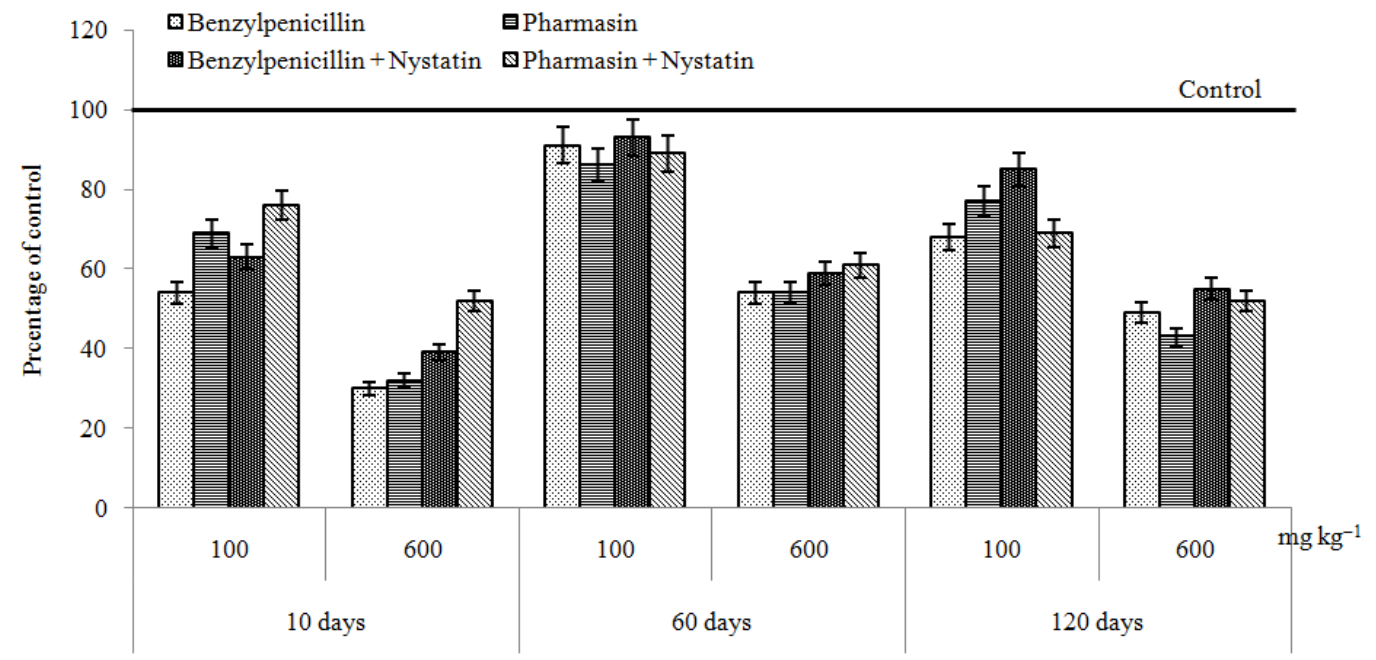

(C) 


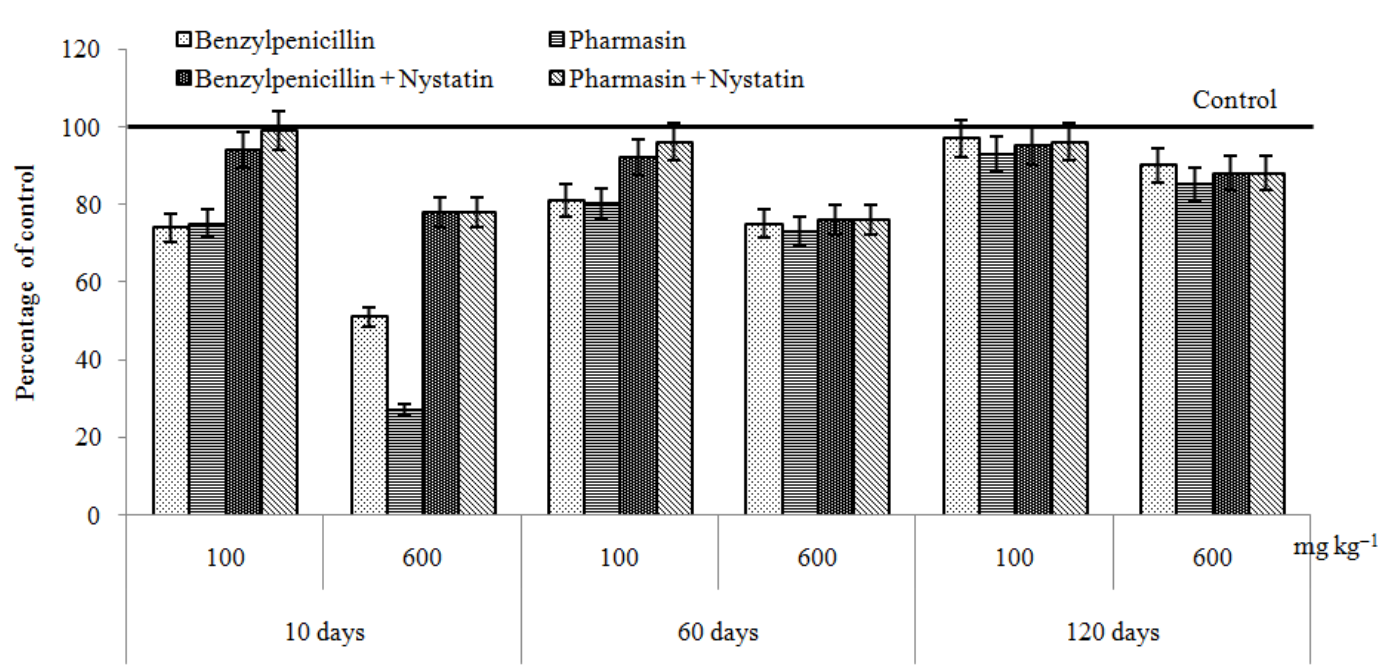

(D)

Fig. 2. The impact of antibiotics on the enzymatic activity of an ordinary chernozem. A (catalase), B (dehydrogenase), C (phosphatase), D (invertase)

We studied the impact of antibiotics on hydrolase (phosphatase and invertase) and oxidoreductase (catalase and dehydrogenase) activities. The results of our experiments arepresented in Fig. 2.

In general, enzymes of the oxidoreductase class were more resistant to antibiotics than enzymes of thehydrolase class. Antibiotics in concentration of 100 $\mathrm{mg} \mathrm{kg}^{-1}$ reliably affected the activity of studied enzymes. The pharmasin-nystatin complex caused maximum inhibition of the catalase activity $(\mathrm{p}<0.001, n=4)$ on the 10th day of the experiment. Restoration of the activities of catalase, dehydrogenase and invertase up to control values was observed during the incubation period; the phosphatase activity was not restored. All the studied antibiotics in concentration $600 \mathrm{mg} \mathrm{kg}^{-1}$ exerted a significant inhibiting action on enzymatic activities. Other researchers demonstrated that antibiotics of tetracycline group in concentration $300 \mathrm{mg} \mathrm{kg}^{-1}$ inhibited the activities of catalase and phosphatase by $35-55 \%$ of the control (Reichel et al., 2014). The maximum decrease in the activities of studied enzymes was observed on the 10th day of the experiment; in the following period, a tendency for restoration of the enzymatic activities was observed. As anticipated, the complexes of antibiotics were most efficient against enzymes. For example, the complex of pharmasin and nystatin inhibited the activities of catalase, dehydrogenase and phosphatase by more than $50 \%(\mathrm{p}<0.001, n=4)$ on the 10 th day of the experiment. In other laboratory experiment (Reichel et al., 2014), a functional shift was indicated by a four-fold reduced acid phosphatase activity in SDZcontaminated soil compared to control soil.

The correlation analysis of the obtained data revealed positive correlation of enzymes of two studied classes (dehydrogenase, invertase) with a number of micromycetes $(r=0.63, r=0.65$, respectively), catalases with ammonifying bacteria $(r=0.73)$ and the return correlation of phosphatase with amylolytic bacteria $(r=$ 0.80 ). It gives the chance to judge a contribution of this or that group of microorganisms in the soil enzymatic pool.

\section{Conclusion}

The following regularities were found in our study of the impact of antibiotics on the biological properties of an ordinary chernozem. In general, antibiotics exerted an inhibiting effect on the biological properties of the chernozem and, particularly, on the soil microorganisms. The studied microorganisms formedthe following sequences according to their resistance to antibiotics: Amylolytic bacteria $>$ micromycetes $>$ ammonifying bacteria. Enzymes of the chernozemwere generally more resistant to the antibiotics than the microorganisms. However, they also differedintheir resistance to antibiotics: Among oxidoreductases, dehydrogenase was more sensitive than catalase; among hydrolases, phosphatase was more sensitive than invertase. In general, oxidoreductases were more resistant to antibiotics than hydrolases. With respect toothier resistance to antibiotics, the studied enzymes formed the following sequence: Catalase $>$ dehydrogenase $>$ invertase $>$ phosphatase.

The recovery of the soil biological properties also followed certain regularities. First, it had a nonlinear character, i.e., an increase in the period of incubation did not necessarily lead to a higher recovery of the studied biological properties. This was particularly pronounced for microorganisms in comparison with the enzymatic 
activity. The recovery pattern of microorganisms after the soil treatment with antibiotics in high concentration (600 $\left.\mathrm{mg} \mathrm{kg}^{-1}\right)$ was as follows: Amylolytic bacteria $>$ ammonifying bacteria $>$ micromycetes. The recovery of enzymatic activity had the following pattern: Dehydrogenase $>$ invertase $>$ catalase $>$ phosphatase. In general, the recovery of the biological properties of the ordinary chernozem after the influence of antibiotics depended on the concentrations of antibiotics: The lower the dose, the quicker the recovery. Upon the high concentrations of the antibiotics (600 mg kg-1), some parameters of the biological properties did not recover even after 120 days.

\section{Acknowledgment}

Investigation was supported by the Ministry of Education and Science of the Russian Federation $(6.345 .2014 / \mathrm{K})$ and by the Leading Scientific Schools program (NSh_2449.2014.4).

\section{Funding Information}

The authors have no support or funding to report.

\section{Author's Contributions}

All authors equally contributed in this work.

\section{Ethics}

This article is original and contains unpublished material. The corresponding author confirms that all of the other authors have read and approved the manuscript and no ethical issues involved.

\section{References}

Akimenko, Y.V., K.S. Kazeev and. K.S. Ilich, 2013a. Dynamics of the enzymatic activity of an ordinary chernozem upon its contamination with antibiotics. Polythematic Online Sci. J. Kuban State Agrarian Univ., 85: 289-298.

Akimenko, Y.V., K.S. Kazeev and S.I. Kolesnikov, 2013 b. The effect of different sterilization procedures on the biological properties of an ordinary chernozem. Soverm. Probl. Nauki and Obrzovan. 6: 721-721.

Akimenko, Y.V., K.S. Kazeev and S.I. Kolesnikov, 2014a. Influence of antibiotics (Benzylpenicillin, pharmazin and nystatin) on the number of microorganisms in ordinary chernozem. Contemp. Probl. Ecol., 7: 204-209.

DOI: $10.1134 / \mathrm{S} 1995425514020024$

Akimenko, Y.V., K.S. Kazeev and S.I. Kolesnikov, 2014b. The impact of antibiotics (Benzylpenicillin and nystatin) on the biological properties of ordinary chernozems. Eurasian Soil Sci., 47: 910-916. DOI: $10.1134 / \mathrm{S} 1064229314070023$
Nakatani, A.S., M.A. Nogueira, A.M. Martines, C.A. Dos Santos and L.F. Baldesin et al., 2012. Effects of tannery sludge application on physiological and fatty acid profiles of the soil microbial community. Appl. Soil Ecol., 61: 92-99.

DOI: 10.1016/j.apsoil.2012.05.003

Andreu, V., P. Vazquez-Roig, C. Blasco and Y. Pico, 2009. Determination of tetracycline residues in soil by pressurized liquid extraction and liquid chromatography tandem mass spectrometry. Anal. Bioanal. Chem., 394: 1329-1339. PMID: 19205670

Barlow, R.S., N. Fegan and K.S. Gobius, 2008. A comparison of antibiotic resistance integrons in cattle from separate beef meat production systems at slaughter. J. Appl. Microbiol., 104: 651-658. PMID: 17927756

Brown, M.G. and D.L. Balkwill, 2009. Antibiotic resistance in bacteria isolated from the deep terrestrial subsurface. Microb. Ecol., 57: 484-493. PMID: 18677528

Campagnolo, E.R., K.R. Johnson, A. Karpati, C.S. Rubin and D.W. Kolpin et al., 2002. Antimicrobial residues in animal waste and water resources proximal to large-scale swine and poultry feeding operations. Sci. Total Environ., 299: 89-95. PMID: 12462576

Chander, Y., K. Kumar, S.M. Goyal and S.C. Gupta, 2005. Antibacterial activity of soil-bound antibiotics. J. Environ. Qual., 34: 1952-1957. PMID: 16221813

Colinas, C., E. Ingham and R. Molina, 1994. Population responses of target and non-target forest soilorganisms to selected biocides. Soil Biol. Biochem., 26: 41-47. DOI: 10.1016/0038-0717(94)90193-7

Dadenko, E.V., K.S. Kazeev, S.I. Kolesnikov and V.F. Val'kov, 2009. Changes in the enzymatic activity of soil samples upon their storage. Eur. Soil Sci., 42: 1380-1385. DOI: 10.1134/S1064229309120084

Denisova, T.V. and K.S. Kazeev, 2008. Sensitivity of some groups of ordinary chernozem soil microorganisms to $\gamma$ irradiation. Russ. J. Ecol., 2: 110-115. DOI: 10.1134/S1067413608020045

Denisova, T.V., K.S. Kazeev, S.I. Kolesnikov and V.F. Val'kov, 2005. The influence of gamma radiation on the biological properties of soil (using the example of ordinary chernozem). Eur. Soil Sci., 38: 776-779.

Denisova, T.V., K.S. Kazeev, S.I. Kolesnikov and V.F. Val'kov, 2011. Integrated evaluation of different electromagnetic impacts on biological properties of soils in southern Russia. Eur. Soil Sci., 44: 1269-1273. DOI: 10.1134/S1064229311090031

Diraz-Cruz, M.S., M.J. Lorpez de Alda and D. Barcelor, 2003. Environmental behavior and analysis of veterinary and human drugs in soils, sediments and sludge. Trendsin Analytical Chem., 22: 340-351. DOI: 10.1016/S0165-9936(03)00603-4 
Galstyan, A.S., 1982. On the resistance of soil enzymes. Pochvovedenie, 4: 108-110.

Galstyan, A.S., 1978. Unification of methods for soil enzyme activity determination. Pochvovedenie, 2: 107-114.

Golet, E.M., I. Xifra, H. Siegrist, A.C. Alder and W. Giger, 2003. Environmental exposure assessment of fluoroquinolone antibacterial agents from sewage to soil. Environ. Sci. Technol., 37: 3243-3249.

DOI: $10.1021 / \mathrm{es} 0264448$

Gulkowska, A., H.W. Leung, M.K. So, S. Taniyasu and N. Yamashita et al., 2008. Removal of antibiotics from wastewater by sewage treatment facilities in Hong Kong and Shenzhen, China. Water Res., 42: 395-403. PMID: 17706267

Hamscher, G., H.T. Pawelzick, H. Hoper and H. Nau, 2005. Different behavior of tetracyclines and sulfonamides in sandy soils after repeated fertilization with liquid manure. Environ. Toxicol. Chem., 24: 861-868. PMID: 15839560

Herron, P.R., I.K. Toth, G.H.J. Heilig, A.D.L. Akkermans and A. Karagouni et al., 1998. Selective effect of antibiotics on survival and gene transfer of Streptomycetes in soil. Soil Biol. Biochem., 30: 673-677.

Höper, H., J. Kues, H. Nau and G. Hamscher, 2002. Eintrag und berbleibvontierarzneimittelwirkstoffen in Böden. Bodenschutz, 4: 141-148.

$\mathrm{Hu}, \mathrm{X}$., Q. Zhou and Y. Luo, 2010. Occurrence and source analysis of typical veterinary antibiotics in manure, soil, vegetables and groundwater from organic vegetable bases, northern China. Environ. Pollut., 158: 2992-2998. PMID: 20580472

Moreno, J.L., A. Aliaga, S. Navarro, T. Hernández and C. García, 2007. Effects of atrazine on microbial activity in semiarid soil. Appl. Soil Ecol., 35: 120127. DOI: $10.1016 /$ j.apsoil.2006.05.002

Karci, A. and I.A. Balcioglu, 2009. Investigation of the tetracycline, sulfonamide and fluoroquinolone antimicrobial compounds in animal manure and agricultural soils in Turkey. Sci. Total Environ., 407: 4652-4664. PMID: 19473691

Kazeev, K.S. and S.I. Kolesnikov, 2012. Biodiagnostics of Soils: Methodology and Methods of Investigation. Izd. Yuzhn. Feder, Univ., Rostov-on-Don, Russian.

Kazeev, K.S., E.S. Loseva, L.G. Borovikova and S.I. Kolesnikov, 2010. The effect of contamination with modern pesticides on the biological activity of an ordinary chernozem. Agrokhimiya, 11: 39-44.

Kemper, N., 2008. Veterinary antibiotics in the aquatic and terrestrial environment. Ecological Indicators 8: 1-13. DOI: 10.1016/j.ecolind.2007.06.002

Kolesnikov, S.I., D.K. Aznaur'yan, K.S. Kazeev and V.F. Val'kov, 2010a. Biological properties of South Russian soils: Tolerance to oil pollution. Russ. J. Ecol., 5: 357-364.

DOI: $10.1134 / \mathrm{S} 1067413610050061$
Kolesnikov, S.I., V.G. Gaivoronskii, E.N. Rotina, K.S. Kazeev and V.F. Val'kov, 2010b. Assessment of soil tolerance toward contamination with black oil in the south of Russia on the basis of soil biological indices: A model experiment. Eur. Soil Sci., 43: 929-934. DOI: 10.1134/S1064229310080107

Kolesnikov, S.I., K.S. Kazeev, M.L. Tatosyan and V.F. Val'kov, 2006. The effect of pollution with oil and oil products on the biological status of ordinary chernozems. Eur. Soil Sci., 39: 552-556.

DOI: $10.1134 / \mathrm{S} 1064229306050127$

Kolesnikov, S.I., N.A. Spivakova and K.S. Kazeev, 2011. The effect of model soil contamination with $\mathrm{Cr}, \mathrm{Cu}, \mathrm{Ni}$ and $\mathrm{Pb}$ on the biological properties of soils in the dry steppe and semidesert regions of southern Russia. Eur. Soil Sci., 44: 1001-1007. DOI: $10.1134 / \mathrm{S} 1064229311090055$

Kolesnikov, S.I., M.V. Yaroslavtsev, N.A. Spivakova and K.S. Kazeev, 2013. Comparative assessment of the biological tolerance of chernozems in the south of Russia towards contamination with $\mathrm{Cr}, \mathrm{Cu}, \mathrm{Ni}$ and $\mathrm{Pb}$ in a model experiment. Eur. Soil Sci., 46: 176-181. DOI: 10.1134/S1064229313020087

Čermák, L., J. Kopecký, J. Novotná, M. Omelka and N. Parkhomenko et al., 2008. Bacterial communities of two contrasting soils reacted differently to lincomycin treatment. Appl. Soil Ecol., 40: 348-358. DOI: 10.1016/j.apsoil.2008.06.001

Malygina, Y.V. and K.S. Kazeev, 2011. The Effect of Antibiotics on the Microflora and Enzymatic Activity of an Ordinary Chernozem. In: Current Problems of Ecology and Nature Management, Kazeev, K.S. (Ed.), Rostizdat, Rostov_on_Don, pp: 68-72.

Zvyagintsev, D.G., 1991. Zvyagintsev, D.G., 1991 and biochemistry. Izd. Mosk. Gos. Univ., Moscow.

Pallecchi, L., A. Bartoloni, F. Paradisi and G.M. Rossolini, 2008. Antibiotic resistance in the absence of antimicrobial use: Mechanisms and implications. Expert Rev., Anti Infect., Ther., 6: 725-732. PMID: 18847408

Pereira, L.A., I.C.S.F. Jardim, A.H. Fostier and S. Rath, 2012. Occurrence behavior and environmental impacts caused by the presence of antimicrobials in veterinary soil. Química Nova, 35: 159-169.

Ramaswamy, J., S.O. Prasher, R.M. Patel, S.A. Hussain and S.F. Barrington, 2010. The effect of composting on the degradation of a veterinary pharmaceutical. Bioresour. Technol., 101: 2294-2299. PMID: 19944598

Renew, J.E. and C.H. Huang, 2004. Simultaneous determination of fluoroquinolone, sulfonamide and trimethoprim antibiotics in wastewater using tandem solid phase extraction and liquid chromatography-electrospray mass spectrometry. J. Chromatography A, 1042: 113-121. DOI: $10.1016 /$ j.chroma.2004.05.056 
Reichel, R., D. Patzelt, C. Barleben, I. Rosendahl and R.H. Ellerbrock et al., 2014. Soil microbial community responses to sulfadiazine-contaminated manure in different soil microhabitats. Appl. Soil Ecol., 80: 15-25. DOI: 10.1016/j.apsoil.2014.03.010

Sarmah, A.K., M.T. Meyer and A.B.A. Boxall, 2006. A global perspective on the use, sales, exposure pathways, occurrence, fate and effects of Veterinary Antibiotics (VAs) in the environment. Chemosphere, 65: 725-759. PMID: 16677683

Schmitt, H., P. van Beelen, J. Tolls and C.L. van Leeuwen, 2004. Pollution-induced community tolerance of soil microbial communities caused by the antibiotic sulfachloropyridazine. Environ. Sci. Technol., 38: 1148-1153. PMID: 14998030

Sirés, I. and E. Brillas, 2012. Remediation of water pollution caused by pharmaceutical residues based on electrochemical separation and degradation technologies: A review. Environ. Int., 40: 212-229. PMID: 21862133

Thiele-Bruhn, S., 2003. Pharmaceutical antibiotic compounds in soils-a review. J. Plant Nutr. Soil Sci., 166: 145-167. DOI: 10.1002/jpln.200390023

Val'kov, V.F., K.S. Kazeev and S.I. Kolesnikov, 2008. Soils of Southern Russia. Everest, Rostov-on-Don.
Yang, S., J. Cha and K. Carlson, 2005. Simultaneous extraction and analysis of 11 tetracycline and sulfonamide antibiotics in influent and effluent domestic wastewater by solid-phase extraction and liquid chromatography-electrospray ionization tandem mass spectrometry. J. Chromatography A, 1097: 40-53. DOI: 10.1016/j.chroma.2005.08.027

Zhang, W., B.S.M. Sturm, C.W. Knapp and D.W. Graham, 2009. Accumulation of tetracycline resistance genes in aquatic biofilms due to periodic waste loadings from swine lagoons. Environ. Sci. Technol., 43: 7643-7650. PMID: 19921873

Zhao, L., Y.H. Dong and H. Wang, 2010. Residues of veterinary antibiotics in manures from feedlot livestock in eight provinces of China. Sci. Total Environ., 408: 1069-1075. PMID: 19954821

Zhou, L.J., G.G. Ying, S. Liu, R.Q. Zhang and H.J. Lai et al., 2013. Excretion masses and environmental occurrence of antibiotics in typical swine and dairy cattle farms in China. Sci. Total. Environ., 444: 183-195. PMID: 23268145 